\title{
Viral antibodies in south polar skuas around Davis Station, Antarctica
}

\author{
GARY D. MILLER ${ }^{1,2 *}$, JOANNE M. WATTS ${ }^{2}$ and GEOFFREY R. SHELLAM ${ }^{2}$ \\ ${ }^{1}$ Department of Biology, University of New Mexico, Albuquerque, NM 87131, USA \\ ${ }^{2}$ Discipline of Microbiology and Immunology, School of Biomedical, Biomolecular and Chemical Sciences, M502, University of Western \\ Australia, Crawley, WA 6009, Australia \\ *Corresponding author: Discipline of Microbiology and Immunology, School of Biomedical, Biomolecular and Chemical Sciences, M502, 35 \\ Stirling Highway, University of Western Australia, Crawley, WA 6009, Australia \\ gdmiller@iinet.net.au
}

\begin{abstract}
We surveyed south polar skuas (Catharacta maccormicki Saunders) in Antarctica for antibodies to a series of viral agents using blood serum and cloacal swabs from 124 adult skuas. There were no ticks on the subjects and we were unable to isolate virus from any individual. Skuas, however, were seropositive to some avian viruses: $16.9 \%(20 / 118)$ had antibodies to infectious bursal disease virus and $10.5 \%(11 / 105)$ were seropositive for Newcastle disease. We found 1.0\% (1/98) had antibodies to avian influenza, no evidence of egg drop syndrome (0/48), but $27.8 \%(10 / 36)$ had antibodies to flaviviruses. Clearly south polar skuas encounter a variety of pathogens either in Antarctica or during their migration in the non-breeding season. There was no evidence of disease in skuas, but the presence of antibodies to pathogens indicates the need to continue to search for the origins of these immunological challenges.
\end{abstract}

Received 3 June 2007, accepted 21 November 2007

Key words: avian disease, avian influenza, infectious bursal disease, Newcastle disease, seroprevalence

\section{Introduction}

The apparent isolation of Antarctica has not spared the continent from invasions of non-native species, including pathogens (Frenot et al. 2005). Antarctic penguins are the best studied avian group, and they are affected by a number of bacterial (Sieburth 1959, Moore \& Cameron 1969, Soucek \& Mushin 1970, Oelke \& Steiniger 1973), viral (Morgan \& Westbury 1981, 1988, Austin \& Webster 1993, Gardner et al. 1997, Gauthier-Clerc et al. 2002) and parasitic infectious agents (Clarke \& Kerry 1993, Clarke \& Kerry 2000). Other bird species in Antarctica, such as the south polar skua (Catharacta maccormicki Saunders), are not so well studied.

Clearly pathogens can be important to bird populations in Antarctica. Avian cholera (Pasteurella multocida) was the cause of a mass death of skuas (Catharacta antarctica (Lesson) and C. maccormicki) and giant petrels (Macronectes giganteus (Gmelin)) near Palmer Station (Parmelee et al. 1979), a southern giant petrel on King George Island (Leotta et al. 2003) and rockhopper penguins (Eudyptes chrysocome (Forster)) on Campbell Island (de Lisle et al. 1990). Avian cholera may also be a major cause in the decline of yellow-nosed albatross (Diomedea chlororhynchos Gmelin) on Amsterdam Island (Weimerskirch 2004).

In addition, mass mortalities have been observed with no clear explanation. No infectious agent was isolated as a result of a mass mortality of Adélie penguin chicks (Pygoscelis adéliae (Hombron \& Jacquinot)) at a colony near Mawson Station in 1972 (Kerry et al. 1996) or a mortality of several hundred gentoo penguin chicks (Pygoscelis papua Forster) on Signy Island (MacDonald \& Conroy 1971). Pasteurella multocida was the suggested cause of a mass mortality of sub-Antarctic skuas at Hope Bay (Montalti et al. 1996) and was confirmed as the agent in two subsequent mortalities there (Leotta et al. 2006).

Coupled with the increased awareness of disease as an issue in Antarctic wildlife, there is concern that increased human activity through tourism (Enzenbacher 1994, Naveen et al. 2001) and scientific stations may bring new disease threats to Antarctic fauna (Curry 2002). For example, Salmonella serotypes isolated from penguins near the Bird Island research station were identified as human pathogens (Olsen et al. 1996) and Campylobacter jejuni subsp. jejuni strains isolated from macaroni penguins (Eudyptes chrysolophus Brandt) at Bird Island are nearly identical to strains from northern hemisphere birds (Broman et al. 2000). Before we can understand the role of humans as agents in spreading pathogens to Antarctic avifauna, we need more basic information about the distribution, dynamics, and origin of pathogens in Antarctica.

Given that many Antarctic seabirds are long-distance travellers, it may be that birds migrating out of the Antarctic ecosystem such as skuas, gulls, terns and giant petrels are important as vectors. Seabirds are known to have brought the agent of Lyme disease, Borrelia burgdorferi, from the northern hemisphere to Bird Island (Olsen et al. 1995), and 


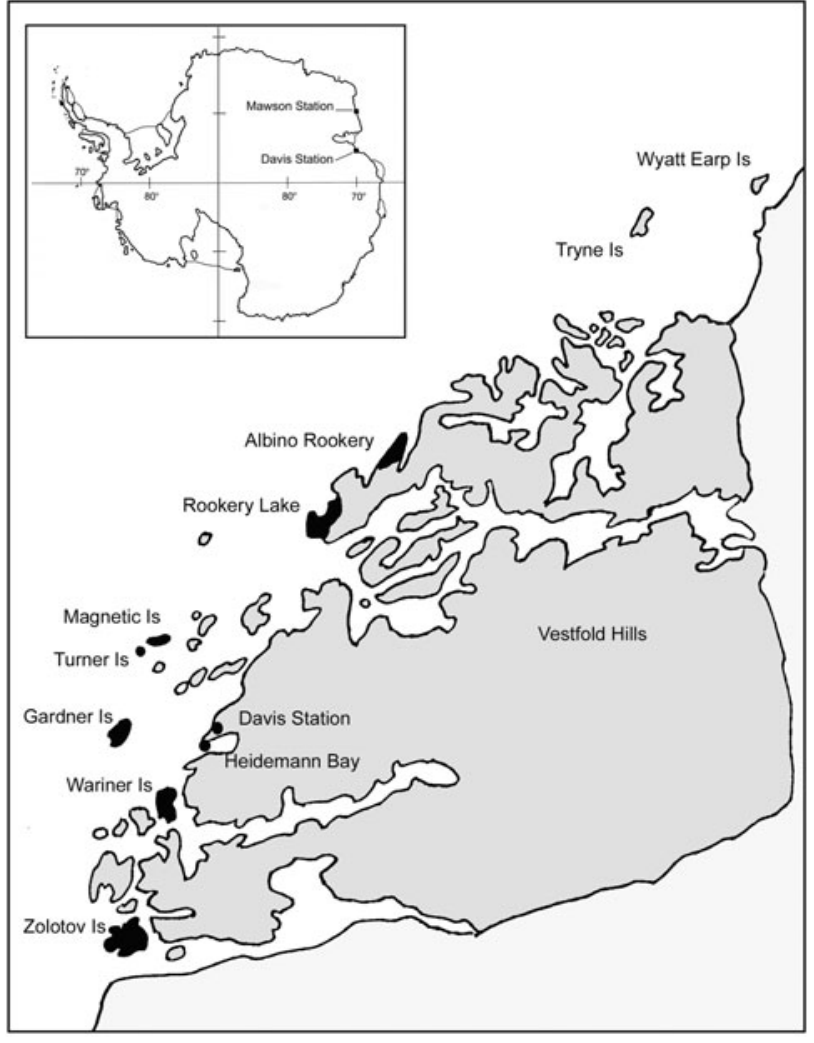

Fig. 1. Map of the study area. Blackened areas indicate the different sampling localities.

king penguins (Aptenodytes patagonicus (Miller)) in the Crozet Archipelago have serum antibodies to this spirochaete (Gauthier-Clerc et al. 1999).

The south polar skua is a strong candidate as a source of introduced pathogens and as a vector of existing pathogens within the continent. As scavengers they are regular visitors to Antarctic stations where they have access to waste material and, despite recent regulations, regularly obtain food scraps from people. They prey on species such as Wilson's storm petrels (Oceanites oceanicus (Kühl)), snow petrels (Pagodroma nivea Forster), cape petrels (Daption capense Linn.) and Antarctic petrels (Thalassoica antarctica (Gmelin)), and nest around penguin colonies to prey on eggs and chicks. In their role as a wide ranging scavenger and predator they are in physical contact with most other bird species. Skuas also migrate long distances during the austral winter. They travel throughout the Atlantic and Pacific Ocean basins and north to the equator in the Indian Ocean during their migration (Furness 1987).

In order to evaluate the importance of south polar skuas as a reservoir and vector for avian disease, we investigated the presence of antibodies to a selection of viral agents which have previously been identified in Antarctic and subAntarctic penguins. We sampled south polar skuas and focused on infectious bursal disease virus (Gardner et al. 1997, Gauthier-Clerc et al. 2002), Newcastle disease virus
(Morgan \& Westbury 1981, 1988, Austin \& Webster 1993), avian influenza virus (Morgan \& Westbury 1981), group III adenovirus Egg drop syndrome 76 (Karesh et al. 1999) and flavivirus (Morgan 1988).

\section{Materials and methods}

The study was conducted in the vicinity of Davis Station, Antarctica $\left(68^{\circ} 34^{\prime} \mathrm{S}, 77^{\circ} 58^{\prime} \mathrm{E}\right)$ during the egg laying and incubation phases, November/December 1999 (Fig. 1). Most of the south polar skuas sampled nested in the vicinity of Adélie penguin colonies in the Vestfold Hills region surrounding Davis Station. We captured breeding birds at Albino Rookery and Rookery Lake on Long Peninsula, and Gardner, Magnetic, Warriner and Zolotov islands. In addition we captured skuas at Davis Station and at nearby Heidemann Bay at a scavenging/club site. A conservative power analysis using a binomial distribution indicates that 150 samples are required from a population in order to be $95 \%$ certain of detecting an agent that infects at least $2 \%$ of the population. All the work was conducted with animal ethics approval from the Australian Antarctic Division (AAD Project number 953).

South polar skuas were caught using two methods. First, territorial skuas were captured on the wing using a hand net (1.1 m diameter). Secondly, non-aggressive birds were caught with a spring-loaded trap baited with locally scavenged penguin or seal carcasses. We fitted each bird with a permanent USFWS-approved leg band before taking samples.

Each subject was sampled for:

A cloacal swab for viral isolation. Swab ends were placed in Brain Heart Infusion Broth (plus antibiotics). They remained at ambient temperature $\left(-5^{\circ}\right.$ to $\left.+5^{\circ} \mathrm{C}\right)$ for $2-5$ hours before they were stored in liquid nitrogen for transport to the laboratory.

A second cloacal swab for bacterial analysis (to be reported on elsewhere). These swabs were stored in Brain Heart Infusion Broth with 20\% glycerol and were treated the same as the cloacal swab for viruses.

A $1.0-2.0 \mathrm{ml}$ blood sample was drawn from a brachial vein. Blood was allowed to clot for at least two hours then centrifuged to harvest the serum. Serum samples were frozen in liquid nitrogen for transport.

Each bird was inspected around the head and face, feet and cloaca for ticks.

Each serum sample was tested for antibodies to a suite of viruses; infectious bursal disease virus (IBDV), Newcastle disease virus (NDV), avian influenza (AI), egg-drop syndrome (EDS76) and flaviviruses. Each test series included negative and positive controls using known samples of chicken sera. 
Table I. Seroprevalence of avian viral antibodies in south polar skuas. ${ }^{1}$

\begin{tabular}{|c|c|c|c|c|c|c|c|c|c|c|c|}
\hline \multirow{2}{*}{ Location } & \multirow{2}{*}{$\begin{array}{l}\text { Distance from } \\
\text { Davis }(\mathrm{km})\end{array}$} & \multicolumn{2}{|c|}{ IBDV } & \multicolumn{2}{|c|}{ NDV } & \multicolumn{2}{|c|}{ AI } & \multicolumn{2}{|c|}{ EDS } & \multicolumn{2}{|c|}{ Flavivirus } \\
\hline & & + ive $/ \mathrm{N}$ & $(\%)$ & + ive $/ \mathrm{N}$ & $(\%)$ & + ive $/ \mathrm{N}$ & $(\%)$ & + ive $/ \mathrm{N}$ & $(\%)$ & + ive $/ \mathrm{N}$ & $(\%)$ \\
\hline Albino rookery & 14.0 & $5 / 31$ & $(16.1)$ & $4 / 29$ & $(13.8)$ & $0 / 27$ & $(0.0)$ & $0 / 15$ & $(0.0)$ & $4 / 13$ & (30.8) \\
\hline Rookery Lake & 9.5 & $4 / 21$ & (19.1) & $0 / 20$ & $(0.0)$ & $0 / 19$ & $(0.0)$ & $0 / 5$ & $(0.0)$ & $0 / 2$ & $(0.0)$ \\
\hline Gardner Island & 3.4 & $0 / 11$ & $(0.0)$ & $2 / 10$ & $(20.0)$ & $0 / 10$ & $(0.0)$ & $0 / 9$ & $(0.0)$ & $0 / 6$ & $(0.0)$ \\
\hline Davis Station & 0.0 & $2 / 6$ & (33.3) & $1 / 6$ & $(16.7)$ & $0 / 5$ & $(0.0)$ & $0 / 2$ & $(0.0)$ & $1 / 1$ & $(100.0)$ \\
\hline Heideman Bay & 0.8 & $4 / 26$ & (15.4) & $0 / 20$ & $(0.0)$ & $0 / 20$ & $(0.0)$ & $0 / 6$ & $(0.0)$ & $1 / 4$ & $(25.0)$ \\
\hline Totals & & $20 / 118$ & $(16.9)$ & $11 / 105$ & $(10.5)$ & $1 / 98$ & (1.0) & $0 / 48$ & $(0.0)$ & $10 / 36$ & $(27.8)$ \\
\hline Median serum titre & & $1 / 64$ & $1 / 8$ & $83 \%$ & & $37 \%$ & & & & & \\
\hline Geometric mean & & \multicolumn{2}{|c|}{$1 / 54$} & \multicolumn{2}{|c|}{$1 / 12.4$} & \multicolumn{2}{|c|}{$83 \%$} & \multicolumn{2}{|c|}{0} & \multicolumn{2}{|c|}{$41 \%$} \\
\hline
\end{tabular}

${ }^{1}$ Results separated by sampling locality and listed from north to south in study area. Table entries represent the number of positive samples/the total samples. IBDV tested by Serum neutralization test with positive screen at 1:20 titre; NDV and EDS tested by haemagglutination inhibition test with positive screen at 1:8 and 1:16 titres respectively; AI and flavivirus tested by competitive ELISA with positive screens at $\geq 60 \%$ and $\geq 30 \%$ inhibition respectively.

Serum antibody titres to IBDV serotype 1 were measured using a standard serum (virus) neutralization test (Westbury \& Fahey 1993). IBDV serotype 1 strain GT101 was used as antigen. Antibody titres are expressed as the reciprocal of the highest dilution which completely inhibited virus. A serum titre of 20 or above for IBDV was considered positive (Giambrone 1980). Antibody titres to NDV and EDS76 were measured using haemagglutination inhibition (HI) tests. Titres of $\geq 8$ were considered positive for NDV (Alexander 1996) and titres $\geq 16$ were considered positive for EDS76. The presence of antibodies to AI and flavivirus was examined using competitive enzyme-linked immunosorbent assays (c-ELISAs). The AI c-ELISA was performed as described by (Selleck 2002), using an antiinfluenza A nucleoprotein monoclonal antibody $(\mathrm{mAb})$. Samples exhibiting $\geq 60 \%$ inhibition are considered positive Selleck (2002). The Flavivirus c-ELISA was performed using flavivirus group specific $\mathrm{mAb} 3 \mathrm{H} 6$ as described by Hall et al. (1995) which is a general test for antibodies to any flavivirus. Inhibition of $\geq 30 \%$ was considered positive for flavivirus specific antibody (Blitvich et al. 2003). All positive samples were tested again by c-ELISA with mAbs specific to two mosquitoborne flaviviruses, Murray Valley encephalitis (MVE) and Kunjin (KUN), using mAbs 10C6 (MVE specific) and 3.1112G (KUN specific) (Hall et al. 1995).

Given the large number of samples and low expectation of finding active virus, the samples were pooled from cloacal swabs into groups of five to conduct virus isolations. We injected an aliquot of each pooled sample into embryonated specific pathogen free (SPF) chicken eggs by the allantoic and chorioallantoic membrane routes for up to three blind passages according to standard procedures of Australian Standard Diagnostic Techniques for Animal Diseases (Corner \& Bagust 1993).

Because IBDV infection can result in immunosuppression and increased susceptibility to secondary infection with a wide range of other avian pathogens (Sharma et al. 2000), a chi-square test for independent samples was used to examine whether skuas that were seropositive for IBDV antibodies were more likely to be seropositive for antibodies for any of the other viral pathogens. We also investigated whether the geographical area was important in creating foci or clusters of IBDV, NDV or flavivirus infection. Using the null hypothesis that the overall prevalence of antibodies for each of the pathogens was uniform throughout the study area, we determined expected results for a chi-squared test for independent samples. Because Gardner et al. (1997) found that the prevalence of IBDV in penguins was greater near Mawson Station than in isolated sites, distance from the station may affect the prevalence of IBDV in skuas. We used regression analysis to determine if the distance from Davis Station would determine the prevalence of any of the antibodies. We normalized the percent prevalence results for 8 separate sampling sites with arcsine transformations then regressed the arcsine of prevalence on distance from Davis Station.

Table II. Serum antibody status for additional viral agents in south polar skuas compared to their status with infectious bursal disease virus $1^{1}$.

\begin{tabular}{lcc}
\hline Virus & \multicolumn{2}{c}{$\begin{array}{c}\text { Infectious Bursal Disease Virus (Serotype 1) } \\
\text { Status }\end{array}$} \\
& Seropositive $n=20$ & Seronegative $n=98$ \\
\hline Newcatle disease virus & 2 & 9 \\
Positive & 14 & 74 \\
Negative & 4 & 15 \\
No test & & 1 \\
Avian influenza & 0 & 88 \\
Positive & 13 & 9 \\
Negative & 7 & 7 \\
No test & & 24 \\
Flavivirus & 2 & 67 \\
Positive & 3 & \\
Negative & 15 & \\
No test & 3 & \\
\hline
\end{tabular}

${ }^{1}$ EDS omitted from table because there were no positive results. 


\section{Results}

We obtained samples from 124 adult skuas in the study area. Twenty individuals of $118(16.9 \%)$ tested had serum neutralizing antibodies to IBDV serotype 1 (Table I). Antibody titres for IBDV ranged from $1 / 20$ to $1 / 256$ (median $=1 / 64)$. Insufficient serum meant fewer tests for the other virus antibodies. Eleven of 105 (10.5\%) skuas tested positive for NDV with a range of antibody titres of $1 / 8$ to $1 / 32$ (median $=1 / 8$ ). One skua in the 98 tested $(1.0 \%)$ was positive to avian influenza with an $83 \%$ inhibition. Ten of $36(27.8 \%)$ were positive for flaviviruses with a range of antibody titres showing inhibition from $31 \%$ to $51 \%($ median $=37 \%)$. All samples were negative for specific antibodies to MVE and KUN and no skuas had antibodies to $\operatorname{EDS76}(n=48)$.

No individual skua tested positive for three of the viral antibodies, but several had antibodies to two viral pathogens (Table II). There was no association, however, with testing positive for IBDV and testing positive for NDV, AI or flavivirus $\left(\chi^{2}=1.4\right.$, d.f. $\left.=1, P>0.20\right)$.

There was no significant clustering of skuas testing positive for IBDV antibodies in any particular locality $\left(\chi^{2}=5.96\right.$, d.f. $\left.=7, P>0.50\right), \mathrm{NDV}\left(\chi^{2}=7.42\right.$, d.f. $=7$, $P>0.30)$ or flavivirus $\left(\chi^{2}=5.41\right.$, d.f. $\left.=7, P>0.50\right)$. Furthermore, there was no significant relationships between testing positive for any of the antibodies and distance from the station. The resulting linear regressions were: IBDV, $\mathrm{y}=0.61 \mathrm{x}+18.7, r=0.20$ and $P>>0.05$; NDV, $\mathrm{y}=0.017 \mathrm{x}+18.7, \quad r=0.017 \quad P>>0.05 ; \quad$ flavivirus, $\mathrm{y}=-3.107 \mathrm{x}+98.09, r=-0.49, P>0.05$, where $\mathrm{y}$ is the arcsine of percent prevalence of each pathogen in each of the eight sampling areas and $\mathrm{x}$ is the distance in kilometres from Davis Station. None were significant regressions.

We found no ticks on any of the skuas. Furthermore, there was no evidence of virus growth in SPF eggs in the virus isolation studies. None of the cloacal swab samples inhibited embryo growth in SPF eggs.

\section{Discussion}

Low pathogenic strains of IBDV are widespread in domestic chickens (Leong et al. 2000) and antibodies to IBDV serotypes 1 and 2 have been detected in a number of freeliving bird species (Nawathe et al. 1978, Wilcox et al. 1983, Gardner et al. 1997, Ogawa et al. 1998, Hollmen et al. 2000, Gauthier-Clerc et al. 2002). This is the first record, however, of IBDV antibodies in a non-penguin species in Antarctica. The prevalence of neutralizing antibodies to IBDV serotype 1 in $16.9 \%$ of adult south polar skuas in this study is lower than the prevalence of IBDV (65.4\%) in emperor penguin chicks reported at Auster Rookery (Gardner et al. 1997). In contrast, Adélie penguin adults and chicks range from no antibodies near Edmonson Point to a high of $2.3 \%$ prevalence in adults near Mawson Station (Gardner et al. 1997). Similarly, adult king penguins on the sub-Antarctic Iles Crozet had a relatively low prevalence (4.8\%) for serotype 1 IBDV (Gauthier-Clerc et al. 2002).

Wild bird species outside of Antarctica generally have low prevalence to IBDV antibodies as well. In one survey of 44 species of wild birds in Japan, the overall prevalence of antibodies to IBDV was $2 \%$ for serotype 1 and $4.9 \%$ for serotype 2 (Ogawa et al. 1998). In comparison, northern hemisphere herring gulls (Larus argentatus Pontoppidan) and eiders have high prevalence of antibodies to serotype 1 IBDV, ranging from $18.0 \%$ in common eiders (Somateria mollissima Linn.) at a remote location to $96.0 \%$ in common eider adults (Hollmen et al. 2000). Clearly antibodies to IBDV are not restricted to domestic fowl and have the potential of being widespread and common in different species.

NDV has been identified in at least 241 species of birds around the world (Kaleta \& Baldauf 1988) and it is likely that all birds are susceptible to infection (Alexander 2000), though outbreaks of clinical disease in wild birds are rare. South polar skuas in this study had relatively high prevalence of antibodies to NDV (10.5\%) compared with other Antarctic species. Most testing in Antarctica has found little or no NDV antibodies. None of the king penguins on Iles Crozet tested positive for NDV antibodies (Gauthier-Clerc et al. 2002). Similarly, king, gentoo and rockhopper penguins on Macquarie Island were free of NDV antibodies (Morgan et al. 1981), but $6.2 \%$ of royal penguins on Macquarie Island tested positive for antibodies to NDV (Morgan et al. 1981). Adélie penguins on Bechervaise Island near Mawson Station had a high $(17.6 \%)$ prevalence of NDV in one sample, but none in a second sample (Morgan \& Westbury 1988).

Avian influenza viruses also occur worldwide and infections have been reported in a variety of different birds and mammals, including people (Clarke \& Hall 2006). Normally, individual influenza virus strains are adapted to a single host species, but they can cross species barriers as is apparent in the spread of the highly pathogenic H5N1 strain of influenza (Clarke \& Hall 2006).

In wild populations, $\mathrm{AI}$ is best known in waterfowl and it is known to be spread by migrating birds (Hansen 1999, Clarke \& Hall 2006). We found antibodies to AI in a single south polar skua out of 98 tested (1.0\%). On Ross Island, no Adélie penguins had antibodies to AI, but 6.7$11.1 \%$ of the south polar skuas were positive for AI antibodies (Austin \& Webster 1993). A recent study of five species (Adélie, chinstrap and gentoo penguins, giant petrel and south polar skuas) found them to vary greatly in the prevalence of AI antibodies (Baumeister et al. 2004). In their samples of skuas, the prevalence of AI varied from $4.3 \%$ at Hope Bay to $28.6 \%$ on King George Island. (Baumeister et al. 2004). In East Antarctica no Adédlie adults near Davis Station had antibodies to AI (Morgan \& 
Westbury 1981, 1988), and just $3.7 \%$ of the adults around Casey Station had antibodies to H7 (Morgan \& Westbury 1981, 1988)

Egg drop syndrome is caused by an avian adenovirus which has been found in wild and domestic ducks, gulls, coots and grebes and serum antibodies have been detected in a variety of species (Merck 2006). We found no evidence, however, of antibody to EDS76 in our sample of 48 south polar skuas. EDS is passed vertically to eggs from adults and the main horizontal transfer is from contaminated eggs (Merck 2006). Skuas are significant predators of eggs, stealing and eating eggs from both penguins and other skuas, so it is likely that the negative result is real.

There were antibodies to flaviviruses in a relatively high percentage $(27.8 \%)$ of south polar skuas around Davis Station using the general HI test. Morgan et al. (1981), who used a single strain of Murray Valley encephalitis (a flavivirus) as antigen for their Macquarie Island study found relatively low levels; royal penguin (2.3\%), king penguin $(7.0 \%)$, rockhopper penguin $(3.2 \%)$ and gentoo penguin $(0.0 \%)$. Flaviviruses require arthropod vectors for transmission, typically ticks, lice or mosquitoes. We found no ticks on any of the skuas sampled in this study and no flying insects occur in Antarctica whereas ticks are common on Macquarie Island penguins (Morgan et al. 1981). It appears that south polar skuas around Davis Station are not exposed to ticks, though biting lice (Mallophaga) have been found on south polar skuas on Ross Island (Schaefer \& Strandtmann 1971, Spellerberg 1971). Our finding of relatively high prevalence of antibodies to flaviviruses in skuas in Antarctica seems paradoxical at first, but by testing for several strains at one time with a general test we were more likely to show more positive results than those using single strains.

Taken together, these studies clearly show that Antarctica is not pristine with regard to pathogens. Studies have now been conducted in East Antarctica, the Ross Sea, the Antarctic Peninsula, Iles Crozet and Macquarie Island all with some positive results. Nevertheless, there are still questions about how these pathogens arrived in Antarctica and how they spread around the continent. Gardner et al. (1997) suggested that humans may be responsible for bringing IBDV to Antarctica because the lowest seroprevalence to IBDV was at their most remote site. We attempted to address that question in this study, but the difference between our nearest and most remote sampling sites was only about $15 \mathrm{~km}$, not great enough to inhibit travel by skuas. Unlike penguins, skuas travel out of the Antarctic ecosystem every year on their winter migration. They travel as far as Greenland, the Gulf of Alaska or the northern Indian Ocean (Furness 1987). Skuas do not normally come to shore during their migration, but they encounter other seabirds, steal food from other birds, and scavenge around fishing boats (Furness 1987) so they have ample opportunity for exposure to pathogens and vectors in temperate and tropical areas around the world. Clearly there is a potential for skuas to introduce pathogens to Antarctica.

From these results, it appears that low to moderate seroprevalences of these viruses $(0.0 \%$ to about $20 \%)$ are typical of Antarctic birds. The example of emperor penguin chicks which range from $65-100 \%$ prevalence of IBDV antibodies (Gardner et al. 1997, JM Watts, unpublished data) is exceptional. How do emperor penguin chicks experience such high levels of exposure? IBDV is a hardy virus that is highly resistant to environmental exposure (van den Berg 2000) so the virus may survive the winter in the penguin colonies.

We are beginning to determine the distribution and prevalence of some viral pathogens in Antarctica, but we still have no evidence of disease from the pathogens discussed here. In addition, little is known about residence times for antibodies in Antarctic birds. Antibody to Avian Paramyxovirus 1 is detectable in little penguins (Eudyptula minor) for just one to three months (Morgan et al. 1985). There also appear to be geographical and temporal variations in the prevalence of these pathogens. In light of increases in the number of humans travelling to Antarctica coupled with climate change which is beginning to affect the productivity of Antarctic seabird populations (Croxall et al. 2002) and which also causes important changes in the distribution of arthropod vectors (Kovats et al. 2001), it is important that we continue to address avian disease in Antarctica.

\section{Acknowledgements}

We thank the Australian Antarctic Division for their generous logistic support for the field work. We also thank the University of New Mexico Biology Department, University of Western Australia, Discipline of Microbiology and Immunology, School of Biomedical, Biomolecular and Chemical Sciences and the personnel of Davis Station (summer of 1999-2000) for their support. Martin Robertson, John Parkinson and Jenny Hills at the Western Australia Department of Agriculture helped us immeasurably with the serological analyses. The project was funded by NSF Office of Polar Programs grant OPP0086212 to GDM and Antarctic Science Advisory Committee (ASAC) grant 953 to GRS.

\section{References}

Alexander, D.J. 1996. Newcastle Disease. In Blancou, J. \& Truszczynski, M., eds. Manual of standards of diagnostic tests and vaccines. Paris: Office of International des Epizooites, 125-134.

Alexander, D.J. 2000. Newcastle disease in ostriches (Struthio camelus) - a review. Avian Pathology, 29, 95-100.

Austin, F.J. \& Webster, R.G. 1993. Evidence of ortho-and paramyxoviruses in fauna from Antarctica. Journal of Wildlife Disease, 29, 568-571. 
Baumeister, E., Leotta, G., Pantoriero, A., Campos, A., Montalti, D., Vigo, G., Pecoraro, M. \& Savy, V. 2004. Serological evidences of influenza A virus infection in Antarctica migratory birds. International Congress Series, 1263, 737-740.

Blitvich, B.J., Marlenee, N.L., Hall, R.A., Calisher, C.H., Bowen, R.A., Roehrig, J.T., Komar, N., Langevin, S.A. \& Beaty, B.J. 2003. Epitope blocking enzyme-linked immunosorbent assays for the detection of serum antibodies to West Nile Virus in multiple avian species. Journal of Clinical Microbiology, 41, 1041-1047.

Broman, T., Bergstron, S., On, S.L.W., Palmgren, H., McCafferty, D.J., Sellin, M. \& Olsen, B. 2000. Isolation and characterization of Campylobacter jejuni subsp.jejuni from macaroni penguins (Eudyptes chrysolophus) in the subantarctic region. Applied Environmental Microbiology, 66, 449-452.

Clarke, J.R. \& Kerry, K.R. 1993. Diseases and parasites of penguins. Korean Journal of Polar Research, 4, 79-96.

Clarke, J.R. \& Kerry, K.R. 2000. Diseases and parasites of penguins. Penguin Conservation, 13, 5-24.

Clarke, L. \& Hall, J. 2006. Avian influenza in wild birds: status as reservoirs, and risks to humans and agriculture. Ornithological Monographs, 60, 3-29.

Corner, L.A. \& Bagust, T.J., eds. 1993. Australian standard diagnostic techniques for animal diseases. Melbourne: Standing Committee on Agriculture and resource Management, $355 \mathrm{pp}$.

Croxall, J.P., Trathan, P.N. \& Murphy, E.J. 2002. Environmental change and Antarctic seabird populations. Science, 297, 1510-1514.

Curry, C.H., McCarthy, J.S., Darragh, H.M., Wake, R.A., Todhunter, R. \& TERRIS, J. 2002. Could tourist boots act as vectors for transmission of infectious agents in Antarctica? Journal of Travel Medicine, 9, $190-193$.

De Lisle, G.W., Stanislawek, W.L. \& Moors, P.J. 1990. Pasteurella multocida infections in rockhopper penguins (Eudyptes chrysocome) from Campbell Island, New Zealand. Journal of Wildlife Diseases, 26, $283-285$.

ENZENBACHER, D.J. 1994. Antarctic tourism: an overview of 1992/93 season activity, recent developments and emerging issues. Polar Record, 30, $105-116$.

Frenot, Y., Chown, S.L., Whinam, J., Selkirk, P.M., Convey, P., Skotnicki, M. \& Bergstrom, D.M. 2005. Biological invasions in the Antarctic: extent, impacts and implications. Biological Reviews, 80, 45-72.

Furness, R.W. 1987. The skuas. Carlton: Poyser, 363 pp.

Gardner, H., Kerry, K., Riddle, M., Brouwer, S. \& Gleeson, L. 1997. Poultry virus infection in Antarctic penguins. Nature, 387, 285.

Gauthier-Clerc, M., Eterradossi, N., Toquin, D., Guittet, M., Kuntz, G. \& Le Maho, Y. 2002. Serological survey of the king penguin, Aptenodytes patagonicus, in Crozet Archipelago for antibodies to infectious bursal disease, influenza A and Newcastle disease viruses. Polar Biology, 25, 316-319.

Gauthier-Clerc, M., Jaulhac, B., Frenot, Y., Bachelard, C., Monteil, H., Le Maho, Y. \& Handrich, Y. 1999. Prevalence of Borrelia burgdorferi (the Lyme disease agent) antibodies in king penguin Aptenodytes patagonicus in Crozet Archipelago. Polar Biology, 22, 141-143.

Giambrone, J.J. 1980. Microculture neutralisation tests for serodiagnosis of three avian viral infections. Avian Diseases, 24, 284-287.

Hall, R.A., Broom, A.K., Harnett, A.C., Howard, M.J. \& Mackenzie, J.S. 1995. Immunodominant epitopes on the NS1 protein of MVE and KUN viruses serve as the targets for a blocking ELISA to detect virusspecific antibodies in sentinel animal serum. Journal of Virological Methods, 51, 201-210.

Hansen, W. 1999. Avian influenza. In Friend, M. \& Franson, J.C., eds. Field manual of wildlife diseases: general field procedures and diseases of birds. Madison, WI: USGS Biological Resources Division, $181-184$.

Hollmen, T., Franson, J.C., Docherty, D.E., Kilpi, M., Hario, M., Creekmore, L.H. \& Petersen, M.R. 2000. Infectious bursal disease virus antibodies in Eider ducks and Herring gulls. Condor, 102, 688-691.
Kaleta, E.F. \& Baldauf, C. 1988. Newcastle disease in freeliving and pet birds. In Alexander, D.J., ed. Newcastle disease. Boston: Kluwer, 197-246.

Karesh, W.B., Uhart, M.M., Frere, E., Gandini, P., Braselton, E., Puche, H. \& Соок, R.A. 1999. Health evaluation of free-ranging rockhopper penguins (Eudyptes chrysocomes) in Argentina. Journal of Zoo Wildlife Medicine, 30, 25-31.

Kerry, K.R., Gardner, H.G. \& Clarke, J.R. 1996. Penguin deaths: diet or disease? Microbiology Australia, 17, 16.

Kovats, R.S., Campbell-Lendrum, D.H., McMichael, A.J., Woodward, A. \& Cox, J.S.H. 2001. Early effects of climate change: do they include changes in vector-borne disease? Philosophical Transactions of the Royal Society of London, B356, 1057-1068.

Leong, J.C., Brown, D., Dobos, P., Kibenge, F.S.B., Ludert, J.E., Mulleer, E. \& Nicholson, B. 2000. Birnaviridae. In VAn Regenmortel, H.V., et al., eds. Virus taxonomy: classification and nomenclature of viruses. New York: Academic Press, 525-537.

Leotta, G.A., Chinen, I., Vigo, G.B., Pecoraro, M. \& Rivas, M. 2006. Outbreaks of avian cholera in Hope Bay, Antarctica. Journal of Wildlife Diseases, 42, 259-270.

Leotta, G.A., Rivas, M., Chinen, I., Vigo, G.B., Moredo, F.A., Coria, N.R. \& Wolcotт, M.J. 2003. Avian cholera in a southern giant petrel (Macronectes giganteus) from Antarctica. Journal of Wildlife Diseases, 39, 732-735.

MacDonald, J.W. \& Conroy, J.W.H. 1971. Virus disease resembling puffinosis in the gentoo penguin Pygoscelis papua on Signy Island, South Orkney Islands. British Antarctic Survey Bulletin, No. 26, 80-83.

MercK. 2006. Merck electronic veterinary manual. http://www. merckvetmanual.com.

Montalti, D., Coria, N.R. \& Curtosi, A. 1996. Unusual deaths of subantarctic skuas Catharacta antarctica at Hope Bay, Antarctica. Marine Ornithology, 24, 39-40.

Moore, B.W. \& CAmeron, A.S. 1969. Chlamydia antibodies in Antarctic fauna. Avian Diseases, 8, 681-684.

Morgan, I.R. 1988. Viruses in Macquarie Island birds. Papers and Proceedings of the Royal Society of New Zealand, 122(1), 193-198.

Morgan, I.R. \& Westbury, H.A. 1981. Virological studies of Adélie penguins (Pygoscelis adeliae) in Antarctica. Avian Diseases, 25, 1019-1027.

Morgan, I.R. \& Westbury, H.A. 1988. Studies of viruses in penguins in the Vestfold Hills, Antarctica. Hydrobiologica, 165, 263-269.

Morgan, I.R., Westbury, H.A. \& Campbell, J. 1985. Viral infections of little blue penguins (Eudyptula minor) along the southern coast of Australia. Journal of Wildlife Diseases, 21(3), 193-198.

Morgan, I.R., Westbury, H.A., Caple, I.W. \& Campbell, J. 1981. A survey of virus infection in sub-Antarctica penguins on Macquarie Island, southern ocean. Australian Veterinary Journal, 57, 333-335.

Naveen, R., Forrest, S.C., Dagit, R.G., Blight, L.K., Trivelpiece, W.Z. \& Trivelpiece, S.G. 2001. Zodiac landings by tourist ships in the Antarctic Peninsula region, 1989-1999. Polar Record, 37, 121-132.

Nawathe, D.R., Onunkwo, O. \& Smith, I.M. 1978. Serological evidence of infection with infection with the virus of infectious bursal disease in wild and domestic birds in Nigeria. Veterinary Record, 102, 444.

Oelke, H. \& Steiniger, F. 1973. Salmonella in Adélie penguins (Pygoscelis adeliae) and south polar skuas (Catharacta maccormicki) on Ross Island Antarctica. Avian Diseases, 17, 568-573.

Ogana, M., Wakuda, T., Yamaguchi, T., Murata, K., Setiyono, A., Fukushi, H. \& Hirai, K. 1998. Seroprevalence of infectious bursal disease virus in free-living wild birds in Japan. Journal of Veterinary Medical Science, 60, 1277-1279.

Olsen, B., Bergstrom, S., McCafferty, D.J., Sellin, M. \& Wistrom, J. 1996. Salmonella enteritidis in Antarctica: zoonosis in man or humanosis in penguins? Lancet, 348, 1319-1320.

Olsen, B., Duffy, D.C., Jaenson, T.G.T., Gylfe, A., Bonnedahl, J. \& Bergstrom, S. 1995. Transhemispheric exchange of Lyme disease spirochetes by seabirds. Journal of Clinical Microbiology, 33, 3270-3274. 
Parmelee, D.F., Maxson, S.J. \& Bernstein, N.P. 1979. Fowl cholera outbreak among brown skuas at Palmer Station. Antarctic Journal of the United States, 14 (5), 168-169.

Selleck, P. 2002. Influenza A virus: a competitive ELISA for the detection of antibodies to avian influenza virus in various sera. Australian Animal Health Laboratory Disease Diagnostic Project, East Melbourne: CSIRO, 1-17.

Schaefer, P.W. \& Strandtmann, R.W. 1971. Notes on incidence and niche preference of Mallophaga and Analgoidea ectoparasitic on south polar skua (Catharacta maccormicki) on Ross Island, Antarctica. Pacific Insects Monograph, 25, 15-16.

Sharma, J.M., Kim, I.-J., Rautenschlein, S. \& YeH, H.-Y. 2000. Infectious bursal disease virus of chickens: pathogenesis and immunosuppression. Developmental and Comparative Immunology, 24, 223-235.

Sieburth, J. 1959. Gastrointestinal microflora of Antarctic birds. Journal of Bacteriology, 77, 521-531.
Soucek, Z. \& Mushin, R. 1970. Gastrointestinal bacteria of certain Antarctic birds and mammals. Applied Microbiology, 20, 561-566.

SpellerberG, I.F. 1971. Mallophaga on the south polar skua (Catharacta skua maccormicki). Pacific Insects Monograph, 25, 19-20.

VAN DEN BERG, T.P. 2000. Acute infectious bursal disease in poultry: a review. Avian Pathology, 29, 175-194.

Weimerskirch, H. 2004. Diseases threaten Southern Ocean albatrosses. Polar Biology, 27, 374-379.

Westbury, H.A. \& Fahey, K.J. 1993. Infectious bursal disease. Virology and serology. In Corner, L.A. \& Bagust, T.J., eds. Australian Standard Diagnostic Techniques for Animal Diseases. Melbourne: Standing Committee on Agriculture and Resource Management, 450 pp.

Wilcox, G.E., Flower, R.L.P., Baxendale, W. \& Mackenzie, J.S. 1983. Serological survey of wild birds in Australia for the prevalence of antibodies to egg drop syndrome 176 (EDS-76) and infectious bursal disease viruses. Avian Pathology, 12, 135-139. 